Int. J. Electrochem. Sci., 11 (2016) 10953 - 10964

\title{
Synthesis and Photophysical Studies of Ru(II) and Co(II) Complexes of bis(benzimidazolyl)pyridine and Evaluation of Their Potential as Sensitizers for Dyes Sensitized Solar Cells
}

\author{
Mathato P. Motaung ${ }^{1}$ and Peter A. Ajibade ${ }^{1, *}$, Lukas J. Le Roux ${ }^{2}$ \\ ${ }^{1}$ Department of Chemistry, University of Fort Hare, Private Bag X1314, Alice 5700, South Africa. \\ ${ }^{2}$ CSIR Materials Science and Manufacturing, P. O. Box 395, Pretoria 001, South Africa. \\ *E-mail: PAjibade@ufh.ac.za
}

doi: $10.20964 / 2016.12 .85$

Received: 21 September 2016 / Accepted: 29 October 2016 / Published: 10 November 2016

\begin{abstract}
We report the synthesis of ruthenium(II) and cobalt(II) complexes of bis(benzimidazolyl)pyridine based ligands formulated as $\left[\mathrm{RuL}_{1} \mathrm{~L}_{\mathrm{n}}(\mathrm{NCS})_{2}\right](\mathbf{C 1}),\left[\mathrm{RuL}_{2} \mathrm{~L}_{\mathrm{n}}(\mathrm{NCS})_{2}\right](\mathbf{C 2}),\left[\mathrm{CoL}_{3} \mathrm{~L}_{\mathrm{n}}(\mathrm{NCS})_{2}\right](\mathbf{C 3})$, $\left[\mathrm{CoL}_{1} \mathrm{~L}_{\mathrm{n}}(\mathrm{NCS})_{2}\right] \quad(\mathbf{C 4}), \quad\left[\mathrm{RuL}_{2} \mathrm{~L}_{\mathrm{n}}(\mathrm{NCS})_{2}\right] \quad(\mathbf{C 5})$ and $\left[\mathrm{RuL}_{3} \mathrm{~L}_{\mathrm{n}}(\mathrm{NCS})_{2}\right]$ (C6) where $\mathrm{L}_{1}=2,6-$ bis(benzimidazolyl)pyridine, $\quad \mathrm{L}_{2}=\quad$ 2,6-bis(butylbenzimidazolyl)pyridine, $\quad \mathrm{L}_{3}=\quad 2,6$ bis(benzylbenzimidazolyl)pyridine and $\mathrm{L}_{\mathrm{n}}=$ pyridine-2,6-dicarboxylic acid. The ligands and complexes were characterized by FTIR and NMR spectroscopy. The complexes exhibited some photoluminescence properties and their photophysical property was influence by the presence of electron donating group. The cyclic voltammogram of the complexes show high negative reduction potentials ascribed to the increased $\pi$ conjugation in the ligands. Three complexes were evaluated as sensitizers for dyes sensitized solar cells with ruthenium(II) complexes of bis(butylbenzimidazolyl)pyridine showing better performance while cobalt(II) complex shows the lowest efficiency.
\end{abstract}

Keywords: Dye-sensitized solar cells; bis(benzimidazolyl)pyridine ligands, photo-electrochemical studies, $\mathrm{Ru}(\mathrm{II})$; $\mathrm{Co}(\mathrm{II})$.

\section{$\underline{\text { FULL TEXT }}$}

(C) 2016 The Authors. Published by ESG (www.electrochemsci.org). This article is an open access article distributed under the terms and conditions of the Creative Commons Attribution license (http://creativecommons.org/licenses/by/4.0/). 